\title{
Taksiran Zakat di Malaysia: Isu dan Cadangan Solusi
}

\author{
Norafzan Awang1, Mohd Rizal Abu Bakar², Wan Syukry Wan Drani³, Zahri Hamat \\ ${ }^{1}$ Fakulti Ekonomi dan Pengurusan, University College Bestari, Putera Jaya, Bandar Permaisuri Setiu, Terengganu, \\ 22100, Malaysia \\ 2 Fakulti Agro Sains, University College Bestari, Putera Jaya, Bandar Permaisuri Setiu, Terengganu, 22100, \\ Malaysia \\ 3 University College Bestari, Putera Jaya, Bandar Permaisuri Setiu, Terengganu, 22100, Malaysia \\ 4 University College Bestari, Putera Jaya, Bandar Permaisuri Setiu, Terengganu, 22100, Malaysia
}

\begin{tabular}{|c|c|}
\hline INFO ARTIKEL & Abstract \\
\hline $\begin{array}{l}\text { Sejarah Artikel: } \\
\text { Diterima : } \\
\text { Diperbaiki } \quad \text { : 6 Februari } 2019 \\
\text { Disetujui } \quad \text { : 6 Februari } 2019 \\
\text { Keywords: } \\
\text { assessment of zakah; income zakah; } \\
\text { benefit in kind; zakah on share. }\end{array}$ & \\
\hline & $\begin{array}{l}\text { In Malaysia, all matters related to zakah are under the jurisdiction of the } \\
\text { Majlis Agama Islam Negeri (MAIN) respectively. Therefore, the diversity of } \\
\text { wealth zakah assessment methods practiced in the states in Malaysia is } \\
\text { difficult to avoid. This paper aims to discuss two things. First, to discuss on } \\
\text { issues relating to the assessment income zakah, and zakah on share. Second, } \\
\text { proposing solutions to the issues in the zakah assessment of the wealth. By } \\
\text { using content analysis of secondary data, research findings show that after } \\
\text { taking into account current and local factors, the benefit in kindis part of the } \\
\text { income that required by zakah. Meanwhile, for zakah on share, the method of } \\
\text { assessment of zakah is determined by the intention and actions of a person } \\
\text { either as an investor or as a trader. } \\
\text { Ahstraks. }\end{array}$ \\
\hline $\begin{array}{l}\text { Kata Kunci: } \\
\text { taksiran zakat; zakat pendapatan; } \\
\text { manfaat berupa barangan; zakat } \\
\text { saham. }\end{array}$ & $\begin{array}{l}\text { Di Malaysia, segala urusan yang berkaitan dengan zakat adalah di } \\
\text { bawah bidang kuasa Majlis Agama Islam Negeri (MAIN) masing- } \\
\text { masing. Oleh sebab itu, kepelbagaian kaedah taksiran zakat kekayaan } \\
\text { yang diamalkan di negeri-negeri di Malaysia sukar dielakkan. Kertas } \\
\text { ini bertujuan untuk membincangkan dua perkara. Pertama, } \\
\text { membahaskan tentang isu-isu yang berkaitan dengan taksiran zakat } \\
\text { pendapatan dan zakat saham. Kedua, mencadangkan solusi terhadap } \\
\text { isu-isu yang terdapat dalam taksiran zakat kekayaan tersebut. Dengan } \\
\text { menggunakan analisis kandungan terhadap data sekunder, dapatan } \\
\text { kajian mempamerkan bahawa setelah mengambil kira faktor semasa } \\
\text { dan setempat, maka manfaat berupa barangan adalah sebahagian } \\
\text { daripada pendapatan yang diwajibkan zakat. Sementara bagi zakat } \\
\text { saham, kaedah taksiran zakatnya adalah ditentukan oleh niat dan } \\
\text { tindakan seseorang sama ada sebagai pelabur ataupun sebagai } \\
\text { pedagang. }\end{array}$ \\
\hline \multicolumn{2}{|c|}{$\begin{array}{l}\text { Koresponsi: } \\
\text { Nama: Norafzan Awang } \\
\text { Email: afzan@ucbestari.edu.my p-ISSN: 2598-7763 }\end{array}$} \\
\hline
\end{tabular}




\section{PENGENALAN}

Zakat adalah aspek penting dalam mengelolakekayaanmasyarakat Muslim. Hal ini kerana dalam kekayaan yang dimiliki itu ada hak atau bahagian ahli masyarakat yang miskin. Yang lebih penting lagi ialah, kekayaan tersebut perlu dibersih dan disucikan. Kaedah untuk membersih kekayaan kekayaan tersebut ialah dengan menunaikan zakat. Allah berfirman yang bermaksud:

"Ambillah (sebahagian) daripada kekayaan (amwal) mereka menjadi sedekah (zakat), (supaya dengannya) engkau membersihkan mereka (daripada dosa) dan menyucikan mereka (daripada akhlak yang buruk) dan doakanlah untuk mereka, disebabkan sesungguhnya doa mu itu menjadi ketenteraman bagi mereka dan (ingatlah) Allah Maha Mendengar, lagi Maha Mengetahui"'(Surah al-Tawbah 9: 103).

Kekayaan didefinisikan sebagai sesuatu yang boleh dikuasai dan dimanfaatkan pada kebiasaannya. Walaupun kekayaan yang disebut dalam al-Qur'an adalah umum, namun jenis kekayaan yang diwajibkan zakat telah diterangkan oleh Rasulullah SAW melalui Sunnah (Yusuf alQaradawi, 2011). Kekayaan tersebut meliputi al'ayn, iaitu emas dan perak, al-tijarah, iaitu perniagaan, al-harth, iaitu pertanian, al-mashiyyah, iaitu ternakan, dan al-rikaz, iaitu hasil bumi. Peraturan dan kaedah taksiran zakat terhadap setiap jenis harta tersebut turut telah ditentukan oleh Rasulullah SAW.

Walau bagaimanapun, sekiranya suasana dan keperluan semasa berubah, kaedah taksiran zakat akan turut berubah. Contohnya, kuda pada masa Rasulullah SAW dikecualikan daripada zakat. Pada masa Rasulullah SAW kuda digunakan hanya untuk peperangan dan pengangkutan. Sebaliknya, semasa pemerintahan Khalifah Umar al-Khattab kuda telah diternak secara komersial, maka kuda telah dikenakan zakat (Abu Ubayd, 1991). Khalifah Umar al-Khattab turut mewajibkan zakat terhadap kacang, buah zaitun, madu dan hasil laut yang tidak diwajibkan zakat sebelum itu.

Menilai semula jenis kekayaan yang dikenakan zakat seperti yang diamalkan oleh Khalifah Umar al-Khattab boleh digunakan untuk sepanjang zaman. Walau bagaimanapun, taksiran zakat terhadap semua kekayaan yang tidak terdapat pada masa dahulu haruslah diqiyaskan pada salah satu daripada lima jenis harta yang telah ditentukan oleh para fuqaha, iaitu emas dan perak, perniagaan, pertanian, ternakan, dan hasil bumi.

\section{Isu Dalam Taksiran Zakat di Malaysia}

Usaha penyelarasan kaedah taksiran zakat dimulakan dengan menerbitkan manual taksiran zakat di Malaysia oleh Jabatan Kemajuan Islam Malaysia (JAKIM) pada tahun 2001 dengan judul Panduan Zakat di Malaysia. Manual ini diterbitkan semula oleh Jabatan Wakaf, Zakat dan Haji (JAWHAR) pada tahun 2008 dengan judul Manual Pengurusan Pengiraan Zakat.Perbincangan dalam manualini boleh dibahagikan kepada dua kategori. Pertama, menjelaskan kaedah taksiran zakat yang berasaskan pendapatan atau penghasilan seperti zakat pendapatan gaji, hasil pertanian, hasil galian. Kedua, menjelaskan kaedah taksiran zakat yang berasaskan aset fizikal atau barangan seperti zakat barangan perniagaan, emas dan perak, binatang ternakan, caruman berkanun serta saham dan bon.

Namun tidak semua kaedah taksiran yang dicadangkan dalam manual itu diamalkan oleh di Majlis Agama Islam Negeri (MAIN). Malah tidak semua kekayaan yang patut dikenakan zakat yang dibahaskan dalam manual tersebut. Antara isuyang sedang dibahaskan di Malaysia ialah pertama, kaedah taksiran zakat pendapatan terhadap MBB; kedua, peranan niat dalam pelaburan saham

Isu Berkaitan Manfaat Berupa Barangan (MBB)

Muzakarah Jawatankuasa Fatwa Majlis Kebangsaan pada 9 Disember 1992, Muzakarah Khas Jawatankuasa Fatwa Majlis Kebangsaan pada 22 Jun 1997 dan Muzakarah Jawatankuasa Fatwa Majlis Kebangsaan pada 7 Mei 2003 memutuskan pendapatan diwajibkan zakat. Zakat diwajibkan pada kadar 2.5 peratus ke atas pendapatan kasar setahun. Manual Pengurusan Pengiraan Zakat, Jabatan Wakaf, Zakat dan Haji (JAWHAR) pada tahun 2008menjelaskan maksud pendapatan seperti berikut:

"Pendapatan merangkumi gaji bulanan, tunggakan gaji, pelbagai elaun seperti elaun kenderaan, makan dan mesyuarat serta lain-lain termasuk bonus atau sesuatu yang boleh dikira sebagai pendapatan yang berkaitan dengan penggajian."

Keputusan fatwa di peringkat negeri turut menjelaskan apa yang dimaksudkan pendapatan. Fatwa Negeri Sarawak pada 23 November 1996 misalnya menyebut pendapatan meliputi gaji gaji, tunggakan gaji, pelbagai elaun dan lain-lain pendapatan yang berkaitan dengan penggajian. Jemaah Ulama' Majlis Agama Islam dan Adat Istiadat Melayu Kelantan pada 16 Mac 1999 menyebut pendapatan meliputi gaji pokok serta lain-lain yang dikira sebagai imbuhan tetap sahaja. Maksud zakat pendapatan penggajian ini turut 
diterangkan dalam laman sesawang di institusi zakat negeri-negeri di Malaysia. Di Pusat Pungutan Zakat Wilayah Persekutuan menerangkan maksud pendapatan lain gaji dan elaun, antaranya ialah dividen, sewaan, royalti, hibah, honorarium.

Maka dapatlah dirumuskan bahawa pendapatan bermaksud gaji, upah, bonus, elaun, pampasan, pencen, dan lain-lain bentuk perolehan semasa hidup, bersara atau mati dan apa jua pendapatan berdasarkan kerjaya. Maksud pendapatan bagi Pusat Zakat Pahang ialah pendapatan yang diperoleh seseorang daripada majikannya hasil daripada usaha atau pekerjaan yang dilakukan untuk majikannya sama ada semasa berkhidmat, selepas berkhidmat atau selepas kematiannya (pencen terbitan) gaji, bonus, tuntutan lebih masa, gratuiti, pampasan, pencen, hadiah, anugerah dan insentif serta skim pilihan saham pekerja (ESOS).

Pada amnya terdapat kesepakatan bahawa pendapatan meliputi apa-apa yang diterima berkaitan dengan penggajian. Manfaat berupa barangan (benefit in kind) adalah manfaat yang diberikan kepada seseorang pekerja oleh pihak majikan akan tetapi manfaat itu tidak boleh ditukar kepada wang. Manfaat berupa barangan (MBB) yang diterima oleh seseorang pekerja antara lain dalam bentuk kemudahan kenderaan, penginapan, kelengkapan perabut dan peralatan dapur (LHDN 2013). Justeru, pendapatan termasuklah lain-lain yang dikira sebagai imbuhan tetap sahaja (Jemaah Ulama' Majlis Agama Islam dan Adat Istiadat Melayu Kelantan), lain-lain pendapatan yang berkaitan dengan penggajian (Fatwa Negeri Sarawak), segala pendapatan yang diperoleh seseorang daripada majikannya hasil daripada usaha atau pekerjaan yang dilakukan untuk majikannya (Pusat Zakat Pahang) dan lain-lain bentuk perolehan semasa hidup, bersara atau mati dan apa jua pendapatan berdasarkan kerjaya (Pusat Pungutan Zakat Wilayah Persekutuan).

Semua maksud tersebut dapatlah dirumuskan bahawa pendapatan adalah apa jua yang diterima yang ada kaitannya dengan sesuatu pekerjaan. Berdasarkan kenyataan itu, apakahMBB adalah sebahagian daripada pendapatan penggajian? Hal ini penting kerana MBB disediakan oleh majikan kepada pekerja dan disebut secara nyata dalam kontrak pekerjaan masing-masing.

\section{Isu Berkaitan Pelaburan Saham}

Menurut Manual Pengurusan Pengiraan Zakat (JAWHAR, 2008), kaedah taksiran zakat saham boleh dibahagikan kepada dua kategori. Pertama, saham yang masih dimiliki selepas cukup haul dikenakan zakat pada kadar 2.5 peratus atas harga terendah antara harga pasaran dan harga belian. Kedua, saham yang dijual beli sepanjang haul dikenakan zakat pada kadar 2.5 peratus atas nilai jualan saham setelah ditolak kos pembelian sahamsaham tersebut (JAWHAR, 2008). Beberapa Majlis Agama Islam Negeri melalui Jawatankuasa Fatwa Negeri masing-masing bagaimanapun turut menetapkan kaedah taksiran zakat saham.

Namun, tidak semua fatwa yang diputuskan adalah sebagaimana yang disarankan oleh JAWHAR. Jawatankuasa Fatwa Negeri Selangor pada 31 Mac 2011 misalnya memutuskan bahawa zakat yang dilaburkan dalam pasaran modal diqiyaskan kepada barangan perniagaan tanpa mengira tujuan pelaburan sama ada untuk diniagakan atau disimpan. Kaedah taksiran zakat saham telah dibahagikan kepada dua kategori.Pertama, taksiran saham dalam bentuk simpanan ditaksirkan berdasarkan nilai saham pada akhir haul. Kedua, saham yang diurusniagakan ditaksir berdasarkan nilai saham pada akhir haul ditambah keuntungan,dan ditolak kos brokeraj.

Negeri-negeri yang menggunakan kaedah perakaunan yang sama bagi kedua-dua bentuk saham tersebut berkemungkinan disebabkan oleh cara interpretasi terhadap saham. Negeri Selangor dan Pulau Pinang misalnya mengqiyaskan saham kepada barangan perniagaan tanpa mengira tujuan pemilikan saham. Oleh yang demikian, kaedah perakaunan zakat saham tidak dibezakan sama ada diurusniaga atau tidak diurusniagakan. Kaedah ini sebenarnya dipelopori oleh Muhammad Abu Zahrah, Abdul Rahman Hasan dan Abdul Wahhab Khallaf (Yusuf al-Qaradawi, 1999). Hal yang sama berlaku di Negeri Sembilan dan Sarawak iaitu menyamakan zakat saham dengan zakat wang simpanan. Maka, zakat dilayan sebagaimana zakat wang simpanan. Zakat dikenakan ke atas nilai terendah antara harga pasaran dan harga kos.

Sementara itu, taksiran zakat saham bagi negeri Pulau Pinang, Selangor, Kedah dan Perlis adalah berdasarkan nilai saham pada akhir haul serta keuntungan. Namun, masih wujud perbezaan dalam mengiktiraf keuntungan atau dividen yang diperoleh. Sebahagian negeri yang mengiktiraf keuntungan tersebut dalam tempoh haul nilai saham semasa. Sebahagian negeri lain pula tidak mengiktiraf keuntungan tersebut sama dengan tempoh nilai semasa saham.

Keadaan ini sebenarnya boleh menimbulkan kekeliruan dalam kalangan masyarakat. Oleh sebab 
itu, satu fatwa di peringkat persekutuan khusus tentang zakat saham dapat dikeluarkan untuk diamalkan di semua negeri di Malaysia. Hal ini pernah ditimbulkan oleh Mufti Negeri Terengganu semasa membentangkan kertas kerja yang berjudul Institusi Fatwa dan Cabaran Semasa. Antara lain beliau menyebut seperti berikut:

“...usaha perlu dilakukan secara bersungguhsungguh untuk menyeragamkan pengeluaran fatwa bagi mengelak kecelaruan fahaman dalam kalangan umat Islam."

Bagi mengelakkan kecelaruandalam kalangan masyarakat, maka beberapa usaha telah diambil untuk menyelaraskan fatwa negeri-negeri di peringkat persekutuan. Seterusnya membuat penambahbaikandalamManual Pengurusan Pengiraan Zakat. Justeru, apakah maksud dan niat pemegangan saham itu sendiri mempengaruhi dalam menentukan kaedah taksiran zakat saham?

\section{Cadangan Solusi Taksiran Zakat di Malaysia}

Sebagaimana yang diterangkan sebelum ini, usaha menyelaraskan kaedah taksiran zakat bermula dengan terbitnya manual taksiran zakat di Malaysia dengan judul Panduan Zakat di Malaysia. Manual ini diterbitkan semula dengan judul Manual Pengurusan Pengiraan Zakat. Namun tidak semua kaedah taksiran yang dicadangkan dalam manual itu diamalkan oleh di Majlis Agama Islam Negeri (MAIN), khususnya tentang kaedah taksiran zakat pendapatan dan pelaburan dalam saham

\section{Solusi Terhadap Manfaat Berupa Barangan (MBB)}

MBB yang biasanya disediakan oleh majikan antara lain dalam bentuk kemudahan kenderaan, penginapan, kelengkapan perabut dan peralatan dapur. MBB itu bagaimanapun diberikan berupa manfaat yang hanya boleh dinikmati oleh pekerja berkenaan dan MBB itu pula tidak boleh ditukar kepada wang. Isunya, mengapakah MBB sepatutnya diwajibkan zakat walaupun pekerja hanya dapat menikmati manfaat dan bukannya diberi dalam bentuk wang?

Bagi menjawab persoalan tersebut, pendapat cendekiawan dalam bidang zakat telah diteroka. Pertama, cendekiawan yang mengkaji tentang perakaunan zakat iaitu Dr. Ram Al-Jefri Saad dari Universiti Utara Malaysia, Dr. Wan Anisah Endut dari Universiti Sultan Zainal Abidin dan Dr. Irfan dari Universiti Muhammadiyah Sumatera Utara. Kedua, cendekiawan yang mengkaji tentang fiqh zakat iaitu Dr. Ridwan Nurdin dari Universiti Islam Negeri al-Raniry, Dr. Jasni Sulong dari Universiti Sains Malaysia dan Dr. Hasanah Abd.
Khafidz dari Universiti Kebangsaan Malaysia. Ketiga, cendekiawan dari institusi zakat iaitu Dr. Amiruddin Muhamed dari Majlis Agama Islam dan Adat Melayu Perak (MAIPk) dan Mohamad Noor Sahidi Johari dari Pusat Pungutan Zakat Wilayah Persekutuan, manakala Nor Diana Anas adalah dari Lembaga Hasil Dalam Negeri.

Dapatan mempamerkan majoriti cendekiawan berpendapat MBB sepatutnya diwajibkan zakat. Hal ini berdasarkan tiga prinsip berikut. Pertama adalah prinsip kekayaan; kedua adalah prinsip keadilan; dan ketiga adalah prinsip objektif Syariah. Kekayaan adalah terdiri daripada harta dalam bentuk fizikal seperti tanah, rumah, ternakan dan saham serta pendapatan seperti hasil pertanian, perniagaan dan penggajian. Seorang cendekiawan fiqh zakat berpendapat bahawa pendapatan bukan sahaja merangkumi pendapatan dalam bentuk kewangan, tetapi ia turut merangkumi pendapatan bukan dalam bentuk kewangan. Secara lebih khusus, seorang cendekiawan daripada institusi zakat menyebut pendapatan bukan dalam kewangan itu bukan sahaja meliputi MBB, malah meliputi manfaat tambang percutian. Beliau antara lain menyebut:

"Zakat dikenakan ke atas pendapatan penggajian, manfaat dan tempat tinggal. Contohnya gaji, ganjaran, manfaat berupa barangan (MBB) dan manfaat tambang percutian."

Seorang cendekiawan perakaunan zakat membuat rumusan seperti berikut:

"Zakat pendapatan dikenakan kepada semua bentuk pendapatan. Oleh sebab itu, ia bukan sahaja pendapatan dalam bentuk kewangan tetapi juga pendapatan bukan dalam bentuk kewangan seperti pelbagai kemudahan ataupun manfaat."

Inilah yang disebut tentang kekayaan wajib zakat dalam al-Quran dan hadis. Dalam bentuk umum, al-Quran menyebut perkataan sebahagian harta (al-Taubah 9: 103) atau hartaharta (alDhariyat 51: 19). Dalam bentuk khusus pula, alQuran menyebut harta-harta seperti emas dan perak (al-Taubah 9: 34), pendapatan pertanian (alAn'am 6: 141), pendapatanperniagaan dan hasil galian (al-Baqarah 2: 267).Yusuf al-Qaradawi (1999) pula membuat rumusan seperti berikut:

"Oleh kerana itu saya berpendapat bahawa keumuman ayat-ayat dan hadis-hadis harus diperhatikan dan diterima sebagai adanya, selama tidak terdapat dalil lain yang benar dan tegas menunjukkan ia berlaku khusus, bila terjadi demikian barulah kita boleh mendahulukan yang khusus daripada yang umum".

Kedua ialah prinsip keadilan di mana 
golongan kaya diwajibkan membayar zakat, manakala golongan miskin tidak diwajibkan zakat. Oleh sebab itulah kekayaan daripada golongan berada (kaya) perlu diagihkan kepada golongan miskin. Hal ini dilaporkan oleh Imam Bukhari daripada Rasulullah SAW telah memberi peringatan ketika mengutuskan Muadh b. Jabal ke Yaman. Beliau berpesan yang bermaksud:

“...Allah memfardhukan kepada mereka menunaikan zakat pada harta mereka. Harta itu diambil daripada orang kaya dan diberikan kepada orang miskin dalam kalangan mereka" (al-Bukhari No. 478).

Seorang cendekiawan fiqh zakat berpendapat bahawa sekiranya MBB boleh dinilai dan memenuhi ciri-ciri harta kekayaan, maka ia boleh diwajibkan zakat. Seorang cendekiawan perakaunan zakat menyokong pendapat tersebut. Antara lain beliauberhujah, oleh sebab MBB itu mempunyai nilai, maka ia perlu diwajibkan zakat. Beliau antara lain menyebut:

"Setuju sekiranya MBB ditaksirkan dalam perakaunan zakat. MBB merupakan satu kemudahan yang disediakan oleh majikan kepada pekerjanya".

Seorang cendekiawan daripada institusi zakat menegaskan bahawa walaupun MBB merupakan manfaat, namun MBB sebenarnya mempunyai nilai dan boleh dinilai untuk ditaksir pendapatan yang diwajibkan zakat dalam bentuk kewangan. Beliau merumuskan seperti berikut:

“...MBB boleh dinilai mengikut jangka hayat sesuatu manfaat. Jangka masa pekerja menikmati manfaat tersebut sama ada atas kepentingan kerja atau kepentingan peribadi, beliau mempunyai hak mutlak ke atas manfaat itu"

Allah SWT telah memberi peringatan kepada golongan kaya seperti firman-Nya yang bermaksud: "Dan pada harta-harta mereka ada hak untuk orang miskin yang meminta dan orang miskin yang tidak mendapat bahagian" (alDhariyat 51: 19).Apatah lagi pendapatan dalam bentuk kewangan digunakan antara lain untuk mendapatkan manfaat seperti untuk makanan, pakaian, tempat tinggal dan pengangkutan. Jika tidak digunakan untuk mendapat semua manfaat tersebut, maka pendapatan penggajian itu akan disimpan ataupun dilaburkan ataupun keduaduanya sekali.

Oleh yang demikian, berdasarkan prinsip keadilan, maka adalah tidak munasabah pekerja yang menerima pendapatan penggajian dalam bentuk manfaat dikecualikan zakat, sedangkan pekerja yang menerima pendapatan dalam bentuk wang diwajibkan zakat.

Ketiga, berdasarkan prinsip al-Maqasid Syariah. Ulama usul fiqh telah mentakrifkan alMaqasid al-Syariah sebagai objektif yang dikehendaki Syarak dalam mensyariatkan sesuatu hukum bagi kemaslahatan umat manusia. Dengan kata lain, maqasid al-Syariah bermaksud objektif yang dikehendaki oleh Syarak melalui sumber alQuran dan al-Sunnah. Seorang cendekiawan fiqh zakat berpendapat bahawa objektif utama zakat ialah untuk membersih dan menyucikan kekayaan serta akhlak pihak muzakki iaitu pembayar zakat. Hal ini disebut oleh Allah dalam surah al-Taubah ayat 103. Beliau antara lain mengatakan:

"Saya berpendapat objektif zakat ialah seperti firman Allah - Ambillah zakat daripada sebahagian harta (amwal) mereka, dengan zakat itu kamu membersihkan dan menyucikan mereka, dan mendoakan untuk mereka - yang lain seperti mengatasi kemiskinan dan mewujudkan keadilan sosio ekonomi merupakan kesan daripada pengagihan zakat"

Ini disokong oleh seorang lagi cendekiawan daripada institusi zakat. Menurut beliau, jika maqasid al-Syariah adalah untuk membersih dan menyucikan kekayaan itu diambil kira, maka seharusnya $\mathrm{MBB}$ itu turut diwajibkan zakat. Dengan itu, MBB yang dinikmati itu dapat dibersih dan disucikan. Di samping itu, dalam MBB yang diterima itu ada hak golongan asnaf yang perlu ditunaikan.

Malah seorang cendekiawan perakaunan zakat merumuskan isu MBB ini seperti berikut:

"Jika majikan telah menyediakan semua keperluan pekerjanya, maka apa-apa pendapatan dalam bentuk wang yang diterima itu tidak akan belanjakan. Wang itu akan disimpan ataupun dilaburkan. Oleh itu, jika wang tunai sahaja yang diwajibkan zakat, maka itu amat tidak adil kepada pekerja lain yang menerima semua pendapatannya dalam bentuk wang tunai dan diwajibkan zakat".

Namun, cendekiawan fiqh zakat membangkitkan antara syarat harta atau pendapatan yang diwajibkan zakat ialah hak milik sempurna. Dalam hal MBB, harta tersebut adalah hak milik majikan, manakala manfaat sahaja yang menjadi milikan pekerja. Seorang cendekiawan merumuskan seperti berikut:

"Syarat bagi pendapatan yang boleh dikenakan zakat antaranya ialah al-mulk al-tam iaitu milikan sempurna. Maksudnya, hanya pendapatan wang atau pendapatan berbentuk harta yang diterima oleh seseorang pekerja yang menjadi milik sempurna beliau sahaja boleh dikenakan zakat 
pendapatan".

Ini bermaksud dengan mempunyai hak milik sempurna, maka pemiliknya bukan sahaja mempuyai hak terhadap harta tersebut tetapi juga mempunyai kuasa untuk menguruskan harta berkenaan. Dalam kes MBB, pemilik mempunyai hak milik sempurna terhadap manfaat harta yang disediakan, manakala harta tersebut adalah menjadi hak milik majikan. Persoalannya, apakah manfaat yang dinikmati adalah harta kerana harta itu sendiri tidak menjadi harta apabila tidak mempunyai manfaat? Persoalan ini memerlukan kajian mendalam yang melibat pelbagai pihak, khususnya pihak Majlis Agama Islam Negeri sendiri.

\section{Solusi Terhadap Pelaburan Saham}

Amalan taksiran zakat saham di Majlis Agama Islam Negeri (MAIN) di Malaysia tidak membezakan antara saham yang diurus niaga dan saham tidak diurusniagakan. Malah negeri Selangor dan Pulau Pinang mengqiyaskan saham kepada barangan perniagaan tanpa mengira tujuan pemilikan saham. Kaedah taksiran begitu sebenarnya dipelopori oleh Muhammad Abu Zahrah, Abdul Rahman Hasan dan Abdul Wahhab Khallaf (Yusuf al-Qaradawi, 1999). Ini berbeza dengan kaedah Islam. Dalam Islam, niat dan tindakan memainkan peranan penting. Hal in berdasarkan hadis Rasulullah SAW yang bermaksud:

"Sesungguhnya setiap amalan itu bergantung kepada niat. Sesungguhnya setiap orang itu akan mendapat sesuatu mengikut niatnya. Sesiapa yang berhijrah kerana Allah dan Rasul-Nya, maka Hijrahnya itu kerana Allah dan Rasul-Nya. Sesiapa yang berhijrah untuk mendapatkan dunia dia akan mendapatkannya atau kerana seorang perempuan yang ingin dikahwininya maka Hijrahnya itu mengikut apa yang diniatkannya" (al-Bukhari: No.1392).

Maka, apakah niat faktor pegangan saham penting dalam penentuan kaedah taksiran zakat saham? Untuk mendapat pandangan terhadap persaolan tersebut tersebut, seramai lima orang cendekiawan di Malaysia telah ditemubual. Pertama, Mufti; kedua, Ahli Jawatankuasa Fatwa Negeri Terengganu; ketiga, Profesor dalam bidang perbankan dan ekonomi kewangan; Keempat, Profesor Madya dalam pengajian Islam; dan kelima, Profesor dalam bidang Ekonomi dan Muamalat.

Dapatan temu bual terhadap lima orang cendekiawan di Malaysia mempamerkan niat pegangan saham boleh mempengaruhi kaedah taksiran zakat saham. Hal ini kerana mereka berpendapat, niat memainkan peranan penting dalam menentukan hukum. Ini bersandar kepada salah satu kaedah fiqh iaitu al-umur bi maqasidiha. Amalan seseorang akan memberi kesan hukum yang berbeza disebabkan perbezaan niat. Kaedah yang sama terpakai bagi kaedah taksiran zakat saham yang antara lain beliau menyebut:

“...sebab niat menjadi garis penentu kepada berlakunya sesuatu hukum. ...peranan niat adalah menentukan hukum sesuatu perkara iaitu kaedah al-umur bi maqasidiha. Sesuatu perkara itu akan menjadi urus niaga perniagaan jika ada niat perniagaan dan zakatnya mestilah berdasarkan kepada apa yang dia niatkan. Maka niat menjadi penentu sesuatu hukum itu dilaksanakan."

Pendapat tersebut disokong seorang cendekiawan lain. Beliau menyebut, niat seseorang memiliki atau memegang saham akan memberi implikasi kepada kaedah taksiran zakat saham tersebut. Saham yang diniat untuk diurusniagakan misalnya ditaksirkan sebagaimana zakat perniagaan. Jika sebaliknya saham yang tidak diniat untuk diurusniagakan, tidak ditaksirkan sebagai zakat perniagaan. Beliau menerangkan seperti berikut:

“...saham adalah untuk diurusniagakan dan tak diurusniagakan yakni disimpan. ...Jika dia memang niat pada masa itu untuk perniagaan, maka kita kira macam zakat perniagaan, jika tidak, maka tidak bolehlah kata zakat perniagaan."

Dalam pada itu, seorang cendekiawan lagi melihat dari sudut matlamat pegangan kekayaan dan mengaitkannya dengan kaedah taksiran zakat saham. Beliau menjelaskan seperti berikut:

"Dalam kes ini, tujuan pelabur adalah penting. ...maka, kaedah yang dibangunkan nanti adalah berdasarkan tersebut. Saya tidak pasti kaedah taksirannya, cuma jika diqiyaskan kepada barangan perniagaan. Method yang dipakai sama sebagaimana zakat barangan perniagaan. Qiyas zakat simpanan, method yang digunakan sama sebagaimana zakat simpanan."

Seorang cendekiawan lagi membuat perbandingan peranan niat dalam taksiran zakat saham dengan zakat emas. Jika emas bertujuan perhiasan, maka emas tersebut tidak dikenakan zakat. Sebaliknya, jika emas untuk disimpan, maka emas tersebut dikenakan zakat. Beliau menyebutnya seperti berikut:

“...taksiran zakat harus dibezakan berdasarkan tujuan atau niat pembelian saham. Kaedahnya pula sebagaimana apa (bentuk kekayaan) yang diqiyaskan. Kalau qiyas kepada 
perniagaan, cara kiranya juga macam perniagaan."

Beliau turut menegur kaedah taksiran zakat terhadap beberapa bentuk kekayaan pada masa kini yang tidak konsisten. Beliau dengan itu mencadangkan kaedah taksiran zakat saham seperti berikut:

"Bukan seperti sekarang, bagi sesetengah sumber kekayaan yang qiyas kepada zakat pertanian, cara kiraan zakat pertanian tetapi kadar 2.5 peratus. Macam zakat pendapatan, ...pada saya, jika sesuatu sumber kekayaan diqiyas kepada sumber kekayaan yang ada pada masa Rasulullah SAW, maka kaedah pengiraan haul, nisab dan kadarnya mesti berdasarkan kepada sumber asal tersebut. Bagi saham yang niatnya untuk dapat dividen tahunan bukan dijual beli saya lebih melihat diqiyaskan kepada zakat hasil pertanian. Zakat kena atas dividen 10 peratus. Kira macam zakat pertanian. Kena atas dividen. Tidak ada syarat haul. Kaedah ini lebih menguntungkan pihak asnaf."

Dengan itu, seorang cendekiawan lain merumuskan kaedah taksiran zakat saham ini seperti berikut:

“...kaedah taksiran zakat harus dibezakan berdasarkan tujuan atau niat pembelian sesuatu saham."

Dapatan kajian mempamerkan niat pegangan sesuatu saham mempengaruhi kaedak taksiran zakat saham. Dengan itu, anggapan semua saham dipegang untuk tujuan perniagaan adalah tidak munasabah. Begitu juga anggapan semua saham dipegang untuk tujuan pelaburan atau simpanan. Hal ini kerana bukan semua saham dipegang dengan niat bagi mendapat keuntungan tahunan semata-mata. Begitulah sebalik bukan semua saham dipegang dengan niat untuk perniagaan sahaja.

Dengan demikian, kerangka taksiran zakat asset yang dibentuk Muhammad Kamal Atiyah (1995) berasaskan kategori kekayaan amat sesuai dipakai. Beliau membahagikan aset kepada dua kategori iaitu pertama ialah aset tetap; dan kedua ialah aset berubah. Aset tetap ialah aset yang digunakan untuk mendapat manfaat daripadanya secara berterusan. Zakat ke atas aset tetap ini dikenakan terhadap pendapatan daripada aset tersebut pada kadar lima peratus, 10 peratus dan 20 peratus. Aset berubah pula ialah aset yang mudah dipindah atau diubah-ubah seperti barangan perniagaan atau aset lain yang mudah ditukar kepada tunai. Zakat ke atas aset berubah ini dikenakan terhadap aset dan pendapatan daripada aset tersebut pada kadar 2.5 peratus. Bagi aset baru ditemui, menurut Muhammad Kamal Atiyah (1995) aset tersebut akan dikategorikan sama ada sebagai aset tetap atau aset berubah. Kaedah taksiran zakatnya bergantung kepada kategori aset tersebut.

Dengan mengambil kira pendapat cendekiawan zakat dan kerangka taksiran zakat yang dibentuk oleh Muhammad Kamal Atiyah (1995), maka kaedah taksiran zakat saham akan dipengaruhi oleh niat sama ada bagi tujuan pemegangan sesutu saham. Jika saham diurusniagakan, maka saham tersebut dikategorikan sebagai aset berubah. Kaedah taksiran zakatnya adalah berdasarkan nilai saham dan keuntungan. Jika saham tidak diurusniagakan, maka saham tersebut dikategorikan sebagai aset tetap. Kaedah taksiran zakatnya adalah berdasarkan keuntungan atau dividen tahunan sahaja. Namun, kedua-dua kategori ini boleh berubah mengikut perubahan niat pegangan saham.

\section{KESIMPULAN}

Dapatan di atas mempamerkan bahawa zakat terhadap MBB agak kurang diambil perhatian sama ada oleh masyarakat mahupun institusi zakat di Malaysia. Malah setakat ini tulisan yang membincangkan tentang kefarduan zakat terhadap MBB amatlah terhad. Walhal MBB itu adalah sebahagian daripada pendapatan penggajian. Perbahasan secara berterusan adalah diperlukan berdasarkan tiga prinsip berikut. Pertama ialah prinsip kekayaan - setiap kekayaan adalah diwajibkan zakat (al-Baqarah 2: 267); kedua, prinsip keadilan - supaya agihan harta itu dapat diambil daripada orang kaya diberikan kepada orang miskin dalam kalangan mereka dapat dilaksanakan (al-Bukhari, No. 478). Ketiga ialah prinsip maqasid al-syariah atau objektif zakat untuk membersih serta menyucikan kekayaan dan akhlak orang Islam dapat direalisasikan (al-Taubah 9: 103). Apatah lagi maksud atau tujuan bendabenda adalah manfaatnya bukan zatnya. Hal ini kerana berlakunya kawalan dan pemilikan ke atas manfaat.

Sementara itu, kaedah perakaunan zakat saham ini sebenarkan dibentuk melalui kaedah aplikasi qiyas. Majoriti responden oleh mengqiyaskan saham kepada sumber harta yang dinaskan secara qat'i. Kaedah perakaunan zakat saham pula dibahagikan kepada dua iaitu perakaunan zakat bagi saham yang diurusniagakan dan saham tidak diurusniagakan. kaedah perakaunan zakat saham pula dibahagikan kepada dua iaitu perakaunan zakat bagi saham yang 
diurusniagakan dan saham tidak diurusniagakan. Kaedah perakaunan zakat bagi saham yang diurusniagakan adalah berdasarkan nilai saham dan keuntungan. Kaedah perakaunan zakat bagi saham yang tidak diurusniagakan pula adalah berdasarkan keuntungan atau dividen tahunan sahaja. JAWHAR sebagai agensi penyelaras di peringkat persekutuan oleh itu perlulah mengambil kira maksud pemegangan saham dalam membentuk kaedah perakaunan zakat saham. Oleh itu penilaian semula kaedah perakaunan zakat saham amat diperlukan kerana maksud dan niat pemegangan zakat itu sendiri merupakan faktor penting dalam menentukan perakaunan zakat saham

\section{DAFTAR PUSTAKA}

al-'Aydarus, Zayn Muhammad Hussayn. 2014. alKhulasah fi Figh al-Mu'amalat wa yalihi alKhulasah fi Figh al-Zakah; Dirasah Fighiyyah Muqaranah. Tarim: Maktabah Tarim alHadithah.

Al-Baihaqi, Ahmad Bin Hussain. 2003. Sunan alKubra Li al-Baihaqi. Tahqiq: Muhammad Abdul Qadir. Beirut: Dar al-Kutub al-'Ilmiyah.

Abu Dawud, Sulaiman. 2004. Sunan Abi Dawud. Tahqiq: Nasr al-Din al-Bani. Riyadh: Maktabah alMa'arif.

Al-Jassas, Ahmad Bin Ali 1992. Ahkam al-Quran. Tahqiq: Muhammad Sadiq al-Qamhawi.Beirut: Dar allhya' al-Turath al-'Arabiy.

Al-Qaradawi, Yusuf .1994. Figh al-Zakah. Kaherah: Maktabah Wahbah.

Al-Qaradhawi, Yusuf .2000. Fiqh al-Zakah. Beirut: Muassasah al-Risalah

AbuUbayd al-Qasim b. Salam.1991. Terj. Noor Mohammad Ghaffari, Kitab al-Amwal, Islamabad: Pakistan Hijra Counsil.

'Atiyah, Mohamad Kamal dan Mohd Nor Ngah. 1995. Perakunan zakat: Terori dan Praktis. Dewan Bahasa dan Pustaka: Kuala Lumpur.

HalizahMdArif, Kasumalinda Alwidan Agoos Munalis Tahir. 2011. Factors Influence Company Towards Zakat Payment: An Explanatory Studies. (Makalah, 2nd International Conference on Business and Economic Research (2nd Icber 2011) Langkawi 13-14 Mac 2011).

Kasumalinda Alwi dan Agoos Munalis Tahir. 2011. Factors Influence Company Towards Zakat Payment: An Explanatory Studies. (Makalah, 2nd International Conference on Business and Economic Research (2nd Icber 2011) Langkawi 13-14 Mac 2011).

Mohamad Zaki Razaly, Mohd Zainodin Mustaffa, Mohd Asyadi Redzuan, Shahrinizam Mansor dan Nurufatinah Umar. 2011. Isu Kutipan Zakat Perniagaan di Negeri Johor: Kajian di Majlis Agama Islam Negeri Johor (MAIJ). International seminar on Islamic Jurisprudence in Contemporary Society.

Mohd Rizuan, A. K .2015. A Framework to Harmonise Shariah Principles and Conditions related to Business Zakat with Accounting Reporting Standards - Malaysian Context. University Sultan Zainal Abidin

Muhammad Ikhlas Rosele, Luqman Hj Abdullah \& Mohd Anuar Ramli .2012., "alQaradawi's Juristic Perspectives on Zakah of Agricultural Wealth As Reflected in His Figh al-Zakah: A Brief Survey." Makalah National Seminar on Contemporary Fiqh: Issues and Challenges, UIAM, 18-19 Disember 2012.

Mujaini Tarimin .2012. Zakat Mal al-Mustafad: Amalan dan Pengalaman di Malaysia. Kuala Lumpur: Pusat Pungutan Zakat.

Sa'di, A. M. 2002. Figh al Zakah was Mustajiddatuha al $M u$ 'asirah.Jordan: Jamilah Mu'tah.

Teh Suhaila Tajuddin. 2017. Business Zakat Accounting and Its Assessment. Jurnal Pengajian Islam. Bil. 10. Isu II, 18-30.

Yusof al-Qaradawi. 1999. Figh az-Zakat: A Comparative Study. Ter. Monzer Kahf, London: Dar Al Taqwa Ltd.

Zahri Hamat. 2014. Perakunan Zakat Perniagaan di Malaysia. Kuala Lumpur:Dewan Bahasa dan Pustaka.

Zahri Hamat. 2015. Harmonization of Business Zakat and Taxation in Malaysia, kertas dibentangkan di $5^{\text {th }}$ International Conference on Management (ICoM 2015), anjuran Czestochowa University of Technology, Slovak University of Agriculturea dan Mendel University bertempat di Godollo, Hungury, 18 - 19 Jun 2015.

Zahri Hamat dan Mohd Shukri Hanapi. 2016. Perakunan Zakat Korporat di Malaysia: Dulu, Kini dan Masa Depan. Melusuri Isu-isu Kontemporari Zakat. Pusat Pungutan Zakat (PPZ). 